\title{
Human poly- and cross-reactive anti-viral antibodies and their impact on protection and pathology
}

\author{
Lucile Warter · Ramapraba Appanna $\cdot$ Katja Fink
}

Published online: 21 March 2012

(C) Springer Science+Business Media, LLC 2012

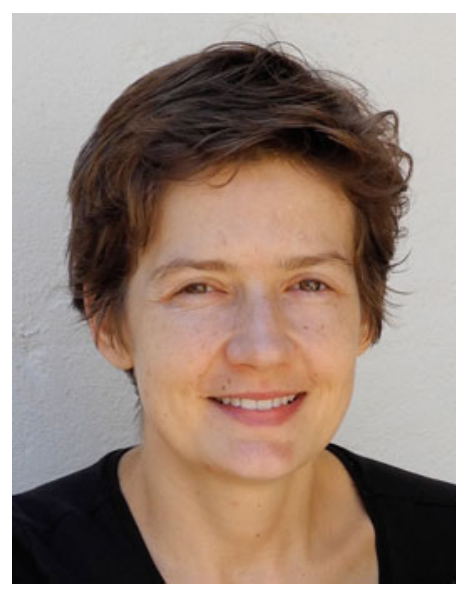

Katja Fink

\begin{abstract}
Anti-viral immune responses have been studied extensively in order to inform rational vaccine design. Following viral infection, the balance of pathologic and protective antibody responses in the host can critically influence clinical outcomes. Comparisons of the different classes of antibodies produced after acute or chronic viral infections have uncovered common features of anti-viral responses, but these analyses have also revealed temporal differences in neutralizing antibody production, variable neutralization potency and differential induction of cross-reactive antibodies. Crossreactive antibodies are known to play crucial protective roles in host responses to chronic viral infections; recent studies in human immunodeficiency virus long-term controllers have identified a novel class of broadly neutralizing antibodies generated from highly mutated and selected memory B cells. Here, we summarize the various roles played by cross- and poly-reactive antibodies in acute and persistent viral infections, with a focus on the potential contribution of these antibodies to dengue virus (DENV) immunopathology and host protection. Since host antibodies profoundly alter the course of viral infections, effective DENV vaccine design will require a better understanding of the origin, affinity maturation and protective potential of the poly-reactive and cross-reactive antibodies induced by different interventions.
\end{abstract}

Keywords B cells · Memory · Plasmablasts · Viral infection · Antibodies · Original antigenic sin · Dengue . Influenza $\cdot \mathrm{HIV} \cdot \mathrm{HCV}$

$\begin{array}{ll}\text { Abbreviations } \\ \text { ASC } & \text { Antibody secreting cell } \\ \text { DENV } & \text { Dengue virus } \\ \text { DF } & \text { Dengue fever } \\ \text { DHF } & \text { Dengue hemorrhagic fever } \\ \text { PB } & \text { Plasmablast } \\ \text { PC } & \text { Plasma cell } \\ \text { HIV } & \text { Human immunodeficiency virus } \\ \text { HCV } & \text { Hepatitis C virus }\end{array}$

Lucile Warter and Ramapraba Appanna contributed equally to this work.

L. Warter · R. Appanna $\cdot$ K. Fink $(\bowtie)$

Singapore Immunology Network (SIgN), Agency for Science,

Technology and Research (A*STAR), 8A Biomedical Grove, \#03 Immunos, Biopolis, Singapore 138648, Singapore

e-mail: Katja_Fink@immunol.a-star.edu.sg

\section{Introduction}

Virus-infected host organisms produce a variety of different classes of antibodies that can influence the efficacy of anti-viral immune responses. When high titers of serotype-specific, highly neutralizing antibodies are produced, the host is protected against later re-infection, and the disease is mild or asymptomatic. In contrast, when cross-reactive, non-neutralizing antibodies prevail, host protection can be limited to the serotype of previous viral infections and allow novel mutant viruses to persist. The efficacy of anti-viral vaccination strategies is similarly modulated by the balance of different antibody classes elicited upon inoculation. The following review summarizes the classes of host antibodies that can alter the course of viral infections and discusses the potential impact of these molecules on viral pathogenesis and vaccine design. 
Natural anti-viral antibodies

Natural antibodies are produced by B cells that have not been selected by infection or vaccination, and the antibodies are not affinity matured [1, 2]. Despite the absence of selection in the periphery, natural antibodies are capable of binding to and neutralizing pathogens, albeit with very low efficacy. The biological importance of natural antibodies directed against bacterial and viral infections has been demonstrated in antibody-deficient mice, which are protected against lethal infections after serum transfer from antibody-competent, pathogen-naïve animals [3-5]. The majority of murine natural antibodies are IgM class and are produced by B-1 cells, an innate B cell population that is abundant in the peritoneum [6], but mice can also produce natural $\mathrm{IgG}$, which protects against intranasal infection with Haemophilus influenzae, suggesting that natural $\mathrm{IgG}$ might play a role in mucosal immunity [7]. In humans, the importance of natural antibodies is most evident in patients with common variable immunodeficiency (CVID) and $\mathrm{X}$-linked agammaglobulinemia (XLA). Both genetic diseases present with very low titers of all Ig isotypes, and patients suffer from common infections of the respiratory and gastrointestinal tracts. Natural antibodies in humans are comprised of IgM, IgG and IgA isotypes [8]. An important direct effect of natural antibodies in human sera is the activation of complement-mediated killing and phagocytosis [9-11]. Natural antibody interactions with complement are essential for clearing oxidatively stressed erythrocytes from the circulation and also help to maintain homeostasis and immunological responsiveness [12]. In addition to the neutralizing effects of natural antibodies and their various complement-mediated functions, indirect effects of natural antibodies have also been reported. For example, human dendritic cell differentiation and maturation are enhanced in the presence of natural antibodies [13].

Methods that permit the cloning and expression of monoclonal antibodies (mAbs) from individual human B cells have progressed tremendously in the past few years, which has facilitated the study of the 'natural' specificities of large repertoires of B cells and antibodies [14-17]. It is now widely accepted that a hallmark of natural antibodies is their poly-reactivity [17-20]. Natural antibodies often bind to self-antigens and have therefore been the subject of extensive study in patients with autoimmune diseases [21, 22]. Even in healthy individuals, self-reactive B cells are abundant at the early stages of differentiation in the bone marrow, yet most are negatively selected, and relatively few self-reactive $B$ cells are evident in the periphery $[23,24]$. Since a positive B-cell receptor (BCR) signal at the pre-B cell stage of differentiation is required for selection $[25,26]$, it is plausible that $\mathrm{B}$ cells that bind to several epitopes may have a survival advantage. In the periphery, poly-reactive $B$ cells that are capable of binding to multiple pathogens provide an efficient immunological defense strategy. Since poly-reactive B cells are present in the organism without prior priming, these B cells can respond immediately after an infection. It remains unclear whether pathogen-specific natural antibodies recognize similar structures to self-reactive antibodies, or whether these molecules represent two genetically and structurally distinct classes of antibodies.

\section{Characteristics of poly-reactive antibodies}

A comparison of the structural, biochemical and genetic features of pathogen-specific and self-specific antibodies can provide insight into the origin and relatedness of these two groups of antibodies. A number of comprehensively characterized poly-reactive antibodies are reported in the literature (Table 1).

A common feature of poly-reactive antibodies appears to be their high level of somatic hypermutation (SHM) and a bias toward certain variable gene usage. We recently observed that dengue virus (DENV)-specific antibodies preferentially use VH1 elements (Xu et al., submitted); a feature that is also shared by antibodies specific for HIV, HCV and influenza (Table 1). Given that VH3 dominates in the natural B-cell repertoire $[19,27]$, it is intriguing that poly- or cross-reactive antibodies with completely unrelated specificities appear predisposed to VH1 usage. VH1*69 elements have been shown to bind to hydrophobic pockets [28, 29]. Highly specific neutralizing antibodies can recognize rapidly mutating, hydrophilic viral epitopes (and possibly also glycosylated epitopes), but antibodies to more conserved hydrophobic residues may also be important for blocking virus entry.

The structural features that define poly-reactivity are not fully understood. Long VH CDR3 regions may be associated with self- or poly-reactivity, but long CDR3 sequences can also be detected in mono-specific antibodies [18, 23]. Structural flexibility of the variable $\mathrm{VH}$ region appears to be a particular hallmark of poly-reactive antibodies [30-32]. However, increased flexibility of VH1 and VH4 sequences relative to $\mathrm{VH} 3$ sequences has yet to be formally demonstrated. Intriguingly, a fraction of $\mathrm{IgG}$ antibodies can acquire or increase poly-specificity upon exposure to denaturing chaotropic agents, low or high $\mathrm{pH}$, high concentrations of salts, ferrous ions and reactive oxygen species [33, 34]. The concept that inflammation induces poly-reactivity was proposed based on the finding that the anti-bacterial binding activity of human $\operatorname{IgG}$ transferred into SCID mice was increased after the mice were treated with complete Freund's adjuvant [35]. However, it is unclear whether this poly-reactivity can be attributed to 


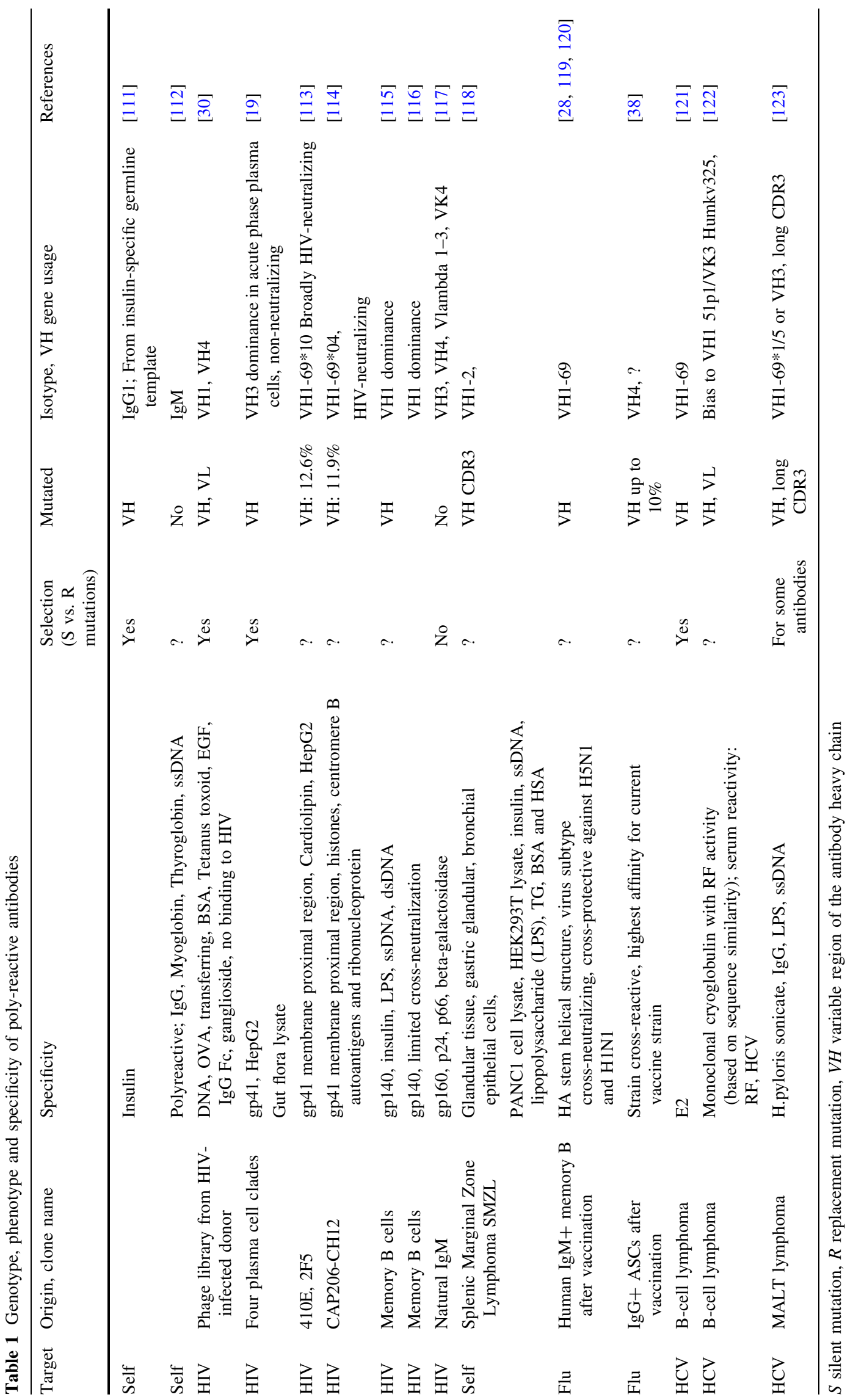


highly mutated clones such as those described in Table 1, or whether the IgG fraction capable of increased binding reactivity was actually comprised of natural antibodies with low binding affinity. Nevertheless, inflammation may impact on antibody poly-reactivity in vivo and could induce secondary rearrangements in memory B cells, resulting in an increased frequency of sequences that incorporate VH1 elements. Several VH1 elements are downstream of $\mathrm{VH} 3$, which are the most commonly used elements in human peripheral blood B cells [36]. It is possible therefore that stepwise B cell re-arrangements could occur via successive germinal center reactions.

Selection and maintenance of poly-reactive memory B cells

Germinal centers (GC) are organized structures where B-cell mutation is triggered by soluble and cell-contact dependent signals. B cells that are capable of interacting with antigen presented in GC are stimulated to proliferate. This process creates competition between $\mathrm{B}$ cells that express low affinity BCRs and those that express a highaffinity BCR for the available antigen, resulting in the selection and survival of high-affinity memory B cells due to their inherent binding advantage.

GC-independent pathways exist for maintaining specific $B$ cells, but the memory cells generated via these routes differ from classical memory B cells. GC-independent memory B cells incorporate fewer mutations and exhibit either an IgG or an IgA phenotype [37]. The SHM of virus-specific, polyreactive antibodies (Table 1) is highly suggestive of selection in GC. For persistent viral infections, selection in GC might be a continuous process, but for acute viral infections such as dengue or influenza, new GC are formed during reinfection, and these are likely to be populated with preexisting memory $\mathrm{T}$ and $\mathrm{B}$ cells. It remains to be determined how poly-reactive B cells as those in Table 1 are maintained in the memory pool without being negatively selected. It is possible that poly-reactive Abs have a competitive advantage because they are selected on self-antigens or structures that are present on commensal bacteria or opportunistic viruses. Moreover, somatically hypermutated B cells with high affinity are preferentially activated during infection [38], and a proportion of these cells might persist in the circulation as memory B cells (Fig. 1).

Of particular relevance in the context of vaccination strategies are the potential negative effects of human crossreactive antibodies that exhibit high affinity and are efficiently re-activated during re-infection. Severe dengue disease is associated with secondary DENV infections, and there are several lines of evidence indicating that crossreactive antibodies can enhance disease symptoms. However, this has not been formally proven in humans. To support the development of novel vaccines, it will be crucial to distinguish antibodies that are merely cross-reactive in vitro from those that can successfully mediate cross-protection in vivo. Antibodies with protective capacity against more than one virus serotype are known to exist, but they are not as potent as serotype-specific protective antibodies [39, 40].

\section{Serotype cross-reactive antibodies in acute and chronic viral infections}

Acute infections: dengue and influenza virusesoriginal antigenic sin

\section{Influenza virus}

'Original antigenic sin' is a phenomenon whereby newly formed antibodies react more strongly with a primary historical antigen than with the current antigen eliciting the
Fig. 1 Types of antibodies generated after viral infections
1) natural antibodies

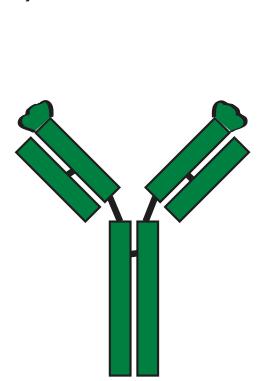

germline

VH3

non-protective 2) cross-reactive
antibodies

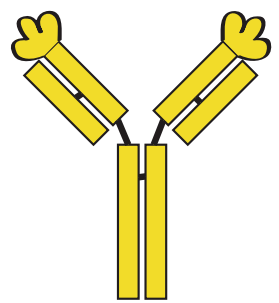

SHM

VH3

non-protective
3) highly neutralizing antibodies

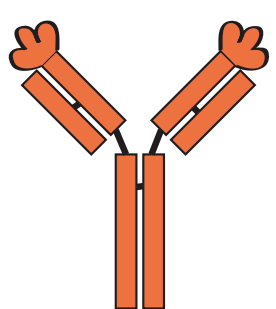

SHM

VH3

highly protective (serotype-specific)
4) poly-reactive antibodies

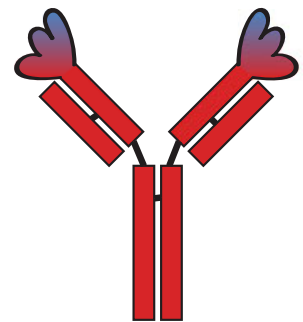

extensive SHM

VH1,

(hydrophobic CDR3)

broadly neutralizing +/- protective 
antibody response. This phenomenon was initially described by Davenport and colleagues, who observed that humans raised only limited antibody responses to infection with new strains of influenza, but simultaneously mounted strong antibody responses to influenza strains that they had previously been infected with [41]. Since this initial observation more than 50 years ago, 'original antigenic sin' has been extensively studied in human influenza infection and in numerous animal models of disease. Recently, the existence of original antigenic sin has been called into question by two studies showing that most of the antibodies generated after virus-specific influenza vaccination in humans do in fact bind to the current vaccine strain with higher affinity than to the previous vaccine strains [38, 42]. However, this discrepancy can most likely be attributed to the use of inactivated influenza vaccine strains in a murine model, which cannot replicate original antigenic sin [43].

\section{Dengue virus (DENV)}

The original antigenic sin phenomenon is a notable feature of sequential human infections with dengue virus (DENV). While DENV infection leads to potentially life-long protection against the infecting serotype, it does not protect against subsequent infections with heterologous serotypes. It is therefore possible for an individual to be infected four separate times by each different strain of DENV. During sequential DENV infections, titers of antibodies specific for the primary serotype remain higher than those specific for the serotype causing ongoing infection. DENV is therefore thought to induce an 'original antigenic sin' effect comparable to that described for influenza [44, 45]. Interestingly, it has been shown that secondary infection with new DENV serotypes also elicits the proliferation of cross-reactive, high-affinity $\mathrm{T}$-cell clones that compete with low-avidity naïve $\mathrm{T}$ cells for the current DENV serotype [46]. These data suggest that a phenomenon analogous to antibody-associated original antigenic sin may also characterize T-cell responses after secondary and sequential DENV infections [46, 47]. While the phenomenon of original antigenic sin has now been well documented, the mechanisms that underpin this effect have not been fully elucidated. Viral induction of original antigenic sin may represent a potential immune escape mechanism [43], and it will be important to determine the factors that drive this effect in order to design more effective novel vaccines.

Until very recently, antibody responses to DENV were investigated primarily in murine models. However, during the last few years, human antibody responses to primary and sequential DENV infections have become increasingly well characterized through the analysis of sera and monoclonal antibodies derived from DENV-infected patients. Human antibody responses to DENV primarily target the envelope protein (E), the precursor membrane (prM) and the nonstructural protein 1 (NS1), although antibody responses targeting alternative nonstructural proteins, including NS3 and NS5, have also been described [45, 48-53].

To date, DENV-specific antibody responses in humans have been investigated largely in recovered patients. Surprisingly, most human antibodies elicited after primary DENV infection appear to be serotype cross-reactive and non-neutralizing, with only a minority of antibodies exhibiting both serotype specificity and neutralizing potency [45, 48-53] (Table 2). Specific antibodies against prM, E domain I, E domain II and NS1 are mostly crossreactive and display poor neutralizing capacity. A major component of the cross-reactive B-cell response during primary DENV infections are prM-specific antibodies. In contrast, E domain III-specific antibodies are highly neutralizing and serotype specific [49, 51], with only a minority exhibiting cross-reactivity. During secondary DENV infections, all cross-reactive antibody responses are drastically amplified, including the cross-reactive and neutralizing E domain III-specific antibodies [45].

Few data are available that describe antibody responses at the single human B-cell level during acute primary or secondary infection with DENV [54]. Mathew and collaborators demonstrated that DENV E protein-specific antibody responses are predominantly serotype specific

Table 2 Onset of cross-reactive antibodies in acute versus chronic human viral infections

\begin{tabular}{|c|c|c|c|}
\hline Infection & Virus & Cross-reactive antibodies: time of onset & References \\
\hline \multirow[t]{4}{*}{ Acute } & \multirow[t]{2}{*}{ Dengue virus } & After primary infections: $5-10$ days & \multirow[t]{2}{*}[51,124]{} \\
\hline & & After repeated infection; $3-5$ days & \\
\hline & \multirow[t]{2}{*}{ Influenza virus } & After primary infections: $\sim 9$ days & {$[125]$} \\
\hline & & After repeated infection: $<7$ days & {$[126]$} \\
\hline \multirow[t]{3}{*}{ Chronic } & \multirow[t]{2}{*}{$\mathrm{HCV}$} & In chronic phase after primary infection & {$[62]$} \\
\hline & & In acute phase after secondary or sequential infection & {$[63]$} \\
\hline & HIV & 2.5 years (rare cases; 1 year) & {$[55]$} \\
\hline
\end{tabular}


during primary infections, while they are highly serotype cross-reactive during and after secondary infections [54]. These data suggest that cross-reactive B cells may have a survival advantage.

Chronic infections: human immunodeficiency virus (HIV) and hepatitis C virus (HCV)

\section{Human immunodeficiency virus (HIV)}

Up to $30 \%$ of patients with chronic HIV-1 infection develop cross-neutralizing antibodies within an average time of 2.5 years postinfection. In rare cases, these crossneutralizing antibodies can be detected as early as 1 year postinfection [55] (Table 2). The fact that cross-reactive neutralizing antibodies may arise several years after initial infection suggests that maturation of the antibody response is necessary to efficiently target conserved viral epitopes [56]. In line with this notion are several studies reporting that the breadth of cross-reactive neutralizing antibody responses correlates with plasma viral load, suggesting that persistent HIV replication is necessary to elicit potent cross-reactive antibodies [57, 58]. While the level of crossneutralizing antibodies does not affect the disease course and resultant immunodeficiency [59,60], the induction of broadly cross-reactive neutralizing antibody responses might yet prove key to the development of an effective HIV vaccine [56, 61].

\section{Hepatitis $C$ virus ( $H C V)$}

Human HCV infections are associated with the induction of cross-reactive antibodies that bind to multiple virus variants. Levels of $\mathrm{HCV}$ cross-reactive antibodies are higher in patients with chronic HCV infection compared with acute $\mathrm{HCV}$ infection, suggesting that cross-reactive antibodies might be induced by amino acid evolution of the virus over the course of disease, due to the virus lacking a proofreading polymerase [62]. In a recent study that compared primary and secondary $\mathrm{HCV}$ infections, spontaneous clearance of the virus was achieved in more than $80 \%$ of re-infected patients compared with only $25 \%$ of primary infections. During the acute phase, cross-reactive antibodies were detected in the majority of re-infected patients who subsequently cleared the virus, but not in patients who progressed to chronic infection [63] (Table 2). The detection of HCV cross-reactive antibodies in patients with chronic infections [62], together with the lack of cross-reactivity in $r e$-infected chronic patients [63], suggests that antibody responses to the virus are markedly different between primary and secondary exposures, and imply a role for cross-reactive antibodies in HCV clearance upon re-infection.

\section{Pathology related to cross-reactive antibodies}

Cross-reactive antibodies in dengue and other viral infection

The most severe form of dengue disease, dengue hemorrhagic fever (DHF), is associated with preexisting immunity to the virus. A study carried out among infants and children in Thailand confirmed that up to $99 \%$ of DHF cases exhibited cross-reactive antibodies against the DENV serotype of infection that caused the DHF [64, 65]. After secondary infection with a heterotypic serotype, the preexisting cross-reactive antibodies form virus-antibody complexes. These complexes bind to Fc receptor-bearing cells, which can lead to virus uptake and replication [50, 66-68]. Further evidence for 'antibody-dependent enhancement' (ADE) of the infection is provided by infants born to mothers with established dengue immunity. The maternally derived DENV-neutralizing IgG elicits protection for several months, but as titers of IgG decline below a protective threshold, infants enter a period of increased DHF risk [69-71]. Another study in Thai children indicated that viral titers in plasma from patients with DHF are higher than those in patients with dengue fever (DF), which is a milder form of the disease [66]. Guzman et al. [72] reported that the majority of DHF cases recorded during the DENV 2 epidemic in Cuba in 1981 occurred in patients with dengue antibodies acquired during the previous DENV 1 epidemics in 1977. Several studies have succeeded in demonstrating ADE in vitro, reporting that virus titers are significantly increased following $\mathrm{Fc}$ receptor $(\mathrm{FcR})$-mediated uptake of virus-antibody complexes by monocytic cells [73-75]. In a monkey model of infection, prior injection of a humanized $\mathrm{mAb}$ increased DENV infection, and this effect was abrogated when the $\mathrm{Fc}$ part of the antibody was mutated to prevent binding to $\mathrm{Fc} \gamma$ receptors $(\mathrm{Fc} \gamma \mathrm{R})$ [67].

Furthermore, ADE also seems to be a mechanism whereby immature or partially mature virions, which cannot attach to host receptors, can still be brought into cells via $\mathrm{F} c \gamma \mathrm{R}$-mediated uptake and produce infectious progeny. Cleavage of the prM structural protein and virion maturation occur once the immature virus-antibody complex is internalized, allowing the virus to fuse with the host cell membrane and release viral RNA into the cell [76]. Intriguingly, the uncleaved prM protein and fusion loop, which are exposed on immature virus particles seem to be highly immunogenic structures that trigger an abundant antibody response [50]. Besides antibodies to immature virus particles, neutralizing $\mathrm{E}$ protein-specific antibodies can also enhance infectivity at low antibody concentrations and weak avidity [71, 77]. However, the lack of relevant animal models of dengue disease has so far prevented a direct proof of the relevance of ADE in humans. 
The phenomenon of ADE of viral infection has been documented in several viruses besides DENV, including respiratory syncytial virus (RSV), hepatitis $\mathrm{C}$ virus (HCV), human immunodeficiency virus (HIV), Ebola virus and Hantavirus [78-82].

ADE of RSV infection was first observed in two monocyte-like cell lines (U937 and THP-1) in the presence of RSV-specific monoclonal antibodies [83]. By blocking the binding of these RSV-specific antibodies, infection of macrophages was significantly diminished. Antibodymediated enhancement of virus uptake into macrophages may contribute to the pathogenesis of RSV bronchiolitis [78].

$\mathrm{HCV}$ often induces persistent infection despite the presence of high levels of anti-viral antibodies. Limited neutralizing activity of $\mathrm{mAb}$ against $\mathrm{HCV}$ pseudotypes has been observed in animals immunized with recombinant $\mathrm{HCV}$ envelope proteins or in sera from chronic $\mathrm{HCV}$ patients. Sera from vaccinees that contain antibodies that bind to the $\mathrm{HCV}$ envelope glycoprotein are unable to efficiently neutralize the infection [81, 84-87]. Further experiments revealed an increase in $\mathrm{HCV}$ pseudotype plaque formation when neutralizing sera were diluted below effective levels. This enhancement of HCV pseudotype titers was shown to be mediated by $\mathrm{Fc} \gamma$ receptor I (Fc $\gamma \mathrm{RI})$ or Fc $\gamma \mathrm{RII}$ [81].

During HIV infection, the cross-linking of virus-activated complement components and virus/antibody conjugates with $\mathrm{Fc}$ receptors or complement receptors has been shown to enhance the infection of susceptible cells. During acute infection, non-neutralizing antibodies which bind to the HIV-1 envelope have been proposed to play a role in HIV-1 dissemination and disease pathogenesis [82]. HIV-1 activates complement, which facilitates viral interactions with host cells that express complement receptors such as CR2, CR3 and CR4 [88]. Interestingly, the CD4 receptor seems to be involved in complement-mediated enhancement of infection. The deposition of complement on the virus brings the gp120 protein close to CD4 molecules on the surface of the cells, eventually leading to viral entry $[82,89]$.

During Ebola Zaire virus infection in humans, antibodies have been shown to play an important role in enhancing viral infectivity [80]. Most strains of Ebola virus trigger a rapidly fatal hemorrhagic disease in humans. Sera derived from recovered patients enhance the infection of primate kidney cells, and this enhancement is mediated by antibodies against viral glycoprotein and involves complement component $\mathrm{Clq}$ [80]. In vitro data from macrophage-like cell lines J774.1, P388D1 and U937 have further demonstrated ADE in hantavirus infection. Monoclonal antibodies to envelope glycoproteins of hantavirus can support ADE activity, whereas antibodies against nucleocapsid protein cannot [79].
Infection-induced autoantibodies and their pathogenic role in dengue and viral diseases

Clinical signs such as fever, thrombocytopenia, hemorrhagic tendency and plasma leakage are key characteristics of severe DENV disease $[90,91]$. In DENV infection, high levels of viral NS1 protein in the circulation alongside preexisting cross-reactive, non-neutralizing antibodies have been shown to activate the complement system, which contributes to vascular leakage. In addition, DENV-specific antibodies that cross-react with host proteins were detected in sera from infected patients $[92,93]$, including anti-platelet IgM antibodies derived from a DHF/DSS patient. In vitro, autoantibodies derived from DHF patient sera exhibit higher binding activity against platelets than antibodies derived from DF patients. These antibodies can also induce platelet lysis through complement activation and inhibition of platelet aggregation [92]. Moreover, the generation of crossreactive autoantibodies against endothelial cells in DHF patients has been proposed to induce endothelial dysfunction [93], and autoantibodies can indeed induce endothelial cell apoptosis in patients infected with different DENV serotypes [94]. Liu $\mathrm{J}$ et al. generated a panel of murine monoclonal antibodies against DENV and showed that an anti-NS1 mAb DB16-1 could cross-react with HUVEC cells and human blood vessels. These data suggested that DB16-1 might act as an autoantibody against the amino acid sequence of LYRIC (Lysine-rich CEACAM1 co-isolated protein) expressed on endothelial cells and drives the transient vascular leakage that occurs in DHF/DSS [95]. The anti-NS1 autoantibodies were shown to specifically cross-react with noninfected endothelial cells and trigger intracellular signaling pathways that lead to the production of nitric oxide (NO) [94], which is typically produced by macrophagelineage cells in order to inhibit DENV replication [96].

One of the proposed mechanisms of DENV-induced autoimmunity is molecular mimicry [97]. A proteomic study and sequence analysis identified homology between the C-terminal region of DENV NS1 with host target proteins. Further sequence homology between coagulation molecules and different regions of the core, prM, E and NS1 virus proteins was also observed. In addition, titers of plasminogen cross-reactive antibodies correlated with the occurrence of hemorrhage in dengue patients, with amino acid sequence 101-106 of E protein displaying similarity to factors XI, X, IX, VII, II (thrombin), plasminogen and tissue plasminogen activator [97-100]. Plasminogen is known as the primary mediator of fibrinolysis [98]. However, with the exception of isolated case reports, patients with DHF usually recover rapidly without any sign of autoimmune disease. The role played by autoantibodies in the pathogenesis of DHF in humans thus remains ambiguous and will require further investigation (Fig. 2). 
Fig. 2 Protective and pathologic mechanisms of antibodies produced after primary and secondary dengue infection
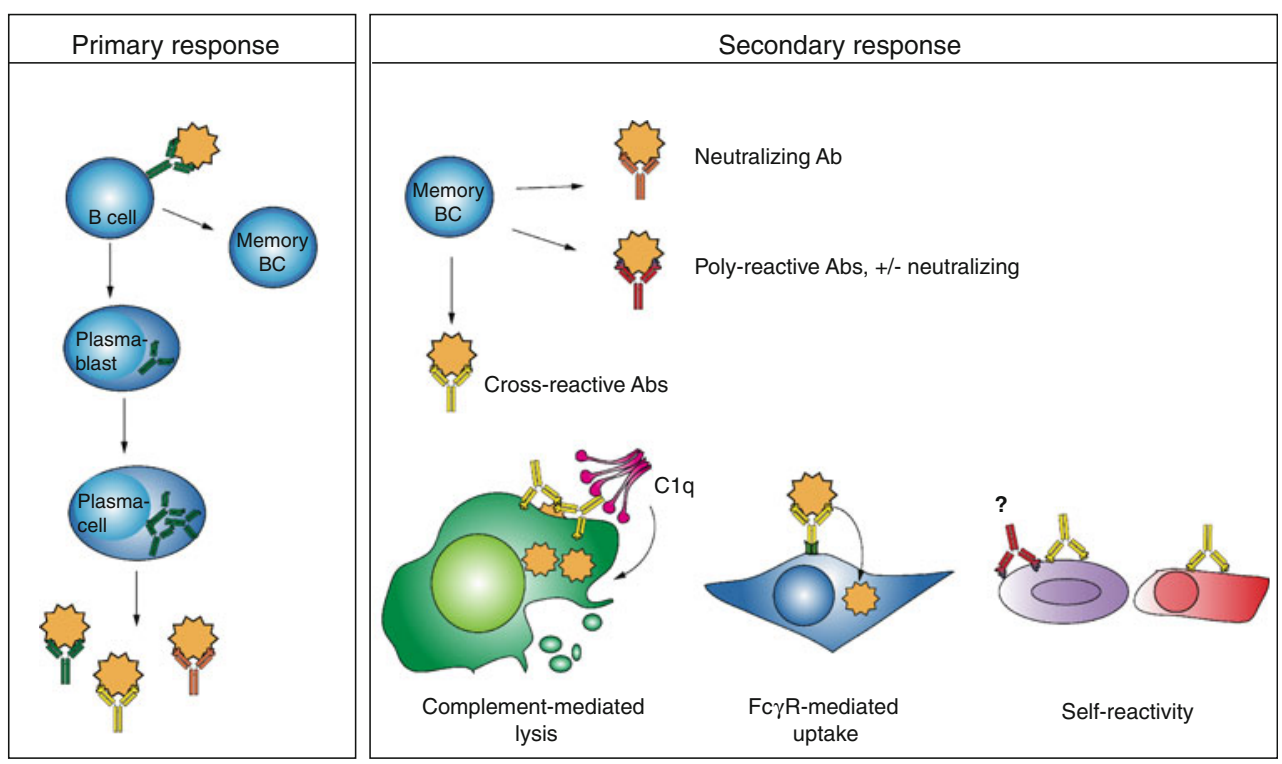

Fig. 3 Protective capacity of different types of antibodies in acute and chronic infections. During chronic infection, the virus mutates (from A to A-1 to A-2, etc.) and escapes the immune response repeatedly, thus enabling new rounds of infection. During acute infections, the virus is controlled before it can accumulate enough mutations to escape the immune response, and neutralizing antibodies are specific for the infecting strain (virus $\mathrm{A}, \mathrm{B}, \mathrm{C}$ or $\mathrm{D}$ )

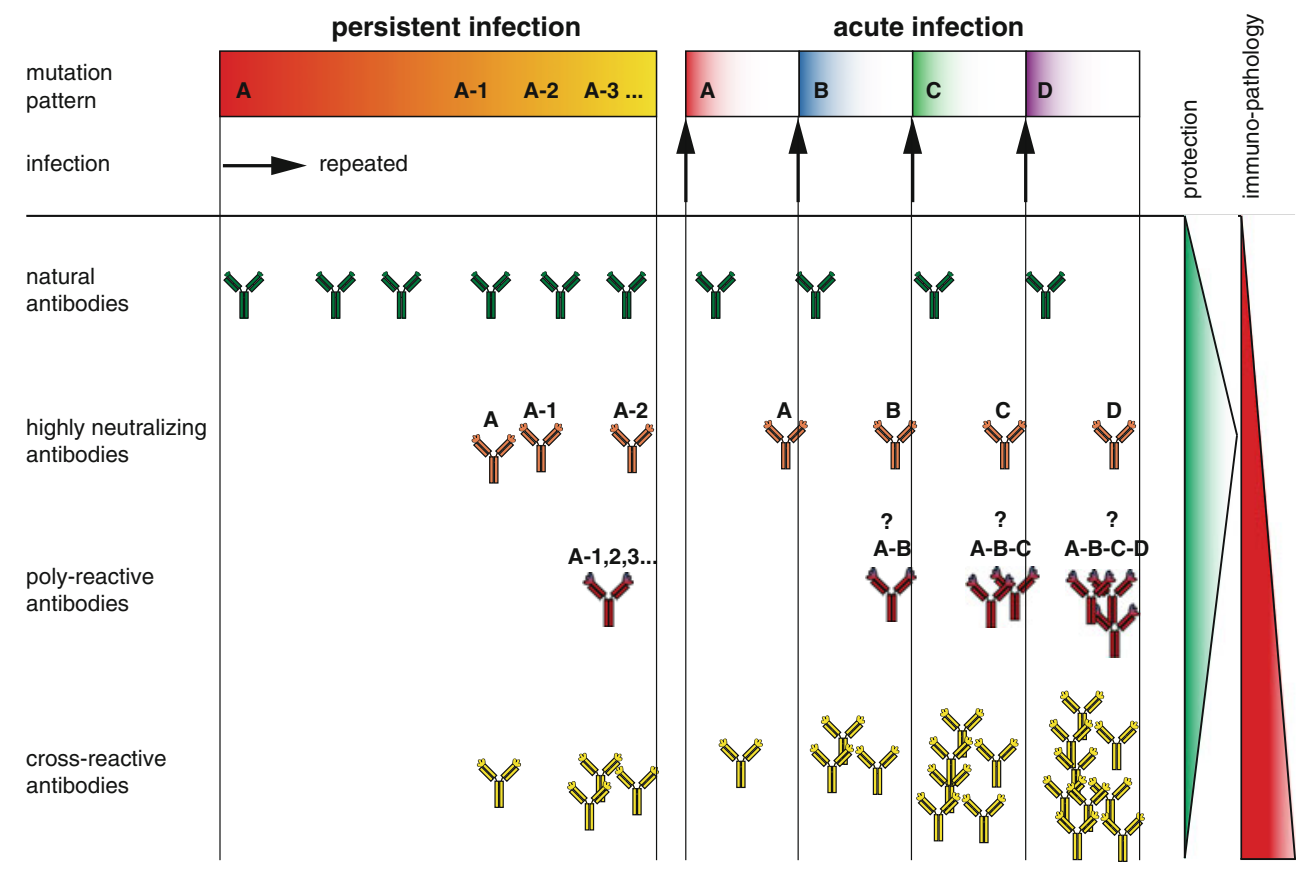

The possible role of molecular mimicry in DENV pathogenesis can also be extended to numerous other viral infections. For example, in AIDS-free HIV patients, molecular mimicry between HIV-gp20 and platelet gpIIIa was suggested to play a role in thrombocytopenia [101]. Similarly, HCV core envelope 1 protein seems to induce thrombocytopenia due to a mimicry with platelet gpIIIa [102]. In $5 \%$ of patients with chronic HCV infection, antiliver-kidney microsome type 1 (LKM1) autoantibodies are directed against cytochrome P450 2D6 (CYP2D6) [103]. Moreover, mixed cryoglobulinemia in $\mathrm{HCV}$-infected patients can cause vascular damage in the liver, kidneys and the skin [104-106].

\section{Conclusions}

An important difference between the viruses described in this review is the extent of amino acid variation among the virus variants, genotypes and serotypes. While HCV has no serotypes, there are six distinct HCV genotypes, and dozens of subtypes and quasi-species are observed in patients 
[107]. Influenza evolves rapidly and undergoes continuous mutation known as 'genetic drift', thus antibodies to closely related variants are still cross-protective. However, no cross-protection occurs if a new subtype of influenza emerges due to re-assortment of two distinct strains (genetic shift) [108]. Given these differences in mutation rates, it can be expected that cross-reactive antibodies will have differing clinical significance in different viral infections (Fig. 3). The enhanced disease severity observed during repeated dengue infections might be related to the genetic similarity of each dengue serotype. The pathogenesis of DENV may therefore result from maintaining a mutation rate high enough to allow immune escape, but simultaneously low enough for efficient binding of crossreactive antibodies to enhance viral uptake by host cells and/or to activate complement.

In chronic viral infections in man, cross-reactive antibodies arise much later than during acute viral infections, suggesting that cross-reactive antibodies might play a positive role in clearance of acute viral infections. While cross-reactive antibodies have long been thought to be of minor importance for the control of HIV, the idea that rare variant cross-neutralizing antibodies might be the key to combating this virus is gaining increasing support [109, 110]. Cross-reactive antibodies associated with $\mathrm{HCV}$ clearance during secondary and sequential infection have also recently been identified [63], further highlighting a possible role for these antibodies in viral control.

'Pathologic antibodies' are non-neutralizing, possibly auto-reactive and/or poly-reactive, and might precipitate and form complexes that cause vascular damage such as that observed in HCV. Immune complex deposition is not well described in dengue disease, but may contribute to the induction of cytokines and the characteristic muscle and joint pain that presents in this disease.

Several dengue candidate vaccines are currently being evaluated. Clinical trials provide an opportunity to study antibody specificity and affinity in longitudinal human samples over several years. This type of research is rarely possible for natural infection, especially since the serotypes and time-points of past infections cannot be reliably determined.

Acknowledgments We would like to thank Neil McCarthy for manuscript editing. This work was funded by the Agency for Science, Technology and Research (A*STAR).

\section{References}

1. Avrameas S. Natural autoantibodies: from 'horror autotoxicus' to 'gnothi seauton'. Immunol Today. 1991;12(5):154-9. Epub 1991/05/01. PubMed PMID: 1715166.
2. Mouthon L, Nobrega A, Nicolas N, Kaveri SV, Barreau C, Coutinho A, et al. Invariance and restriction toward a limited set of self-antigens characterize neonatal IgM antibody repertoires and prevail in autoreactive repertoires of healthy adults. Proc Natl Acad Sci USA. 1995;92(9):3839-43. Epub 1995/04/25. PubMed PMID: 7731992; PubMed Central PMCID: PMC42057.

3. Briles DE, Nahm M, Schroer K, Davie J, Baker P, Kearney J, et al. Antiphosphocholine antibodies found in normal mouse serum are protective against intravenous infection with type 3 streptococcus pneumoniae. J Exp Med. 1981;153(3):694-705. Epub 1981/03/01. PubMed PMID: 7252411; PubMed Central PMCID: PMC2186108.

4. Jayasekera JP, Moseman EA, Carroll MC. Natural antibody and complement mediate neutralization of influenza virus in the absence of prior immunity. J Virol. 2007;81(7):3487-94. Epub 2007/01/05. doi:10.1128/JVI.02128-06. PubMed PMID: 17202212; PubMed Central PMCID: PMC1866020.

5. Ochsenbein AF, Fehr T, Lutz C, Suter M, Brombacher F, Hengartner $\mathrm{H}$, et al. Control of early viral and bacterial distribution and disease by natural antibodies. Science. 1999; 286(5447):2156-9. Epub 1999/12/11. PubMed PMID: 10591 647.

6. Choi YS, Baumgarth N. Dual role for B-1a cells in immunity to influenza virus infection. J Exp Med. 2008;205(13):3053-64. Epub 2008/12/17. doi:10.1084/jem.20080979. PubMed PMID: 19075288; PubMed Central PMCID: PMC2605232.

7. Zola TA, Lysenko ES, Weiser JN. Natural antibody to conserved targets of Haemophilus influenzae limits colonization of the murine nasopharynx. Infect Immun. 2009;77(8):3458-65. Epub 2009/05/20. doi:10.1128/IAI.01564-08. PubMed PMID: 19451240; PubMed Central PMCID: PMC2715656.

8. Cohen IR, Norins LC. Natural human antibodies to gram-negative bacteria: immunoglobulins G, A, and M. Science. 1966;152(726):1257-9. Epub 1966/05/27. PubMed PMID: 5327 885.

9. Navin TR, Krug EC, Pearson RD. Effect of immunoglobulin M from normal human serum on Leishmania donovani promastigote agglutination, complement-mediated killing, and phagocytosis by human monocytes. Infect Immun. 1989;57(4): 1343-6. Epub 1989/04/01. PubMed PMID: 2925255; PubMed Central PMCID: PMC313275.

10. Takeuchi Y, Liong SH, Bieniasz PD, Jager U, Porter CD, Friedman T, et al. Sensitization of rhabdo-, lenti-, and spumaviruses to human serum by galactosyl(alpha1-3)galactosylation. J Virol. 1997;71(8):6174-8. Epub 1997/08/01. PubMed PMID: 9223512; PubMed Central PMCID: PMC191878.

11. Ehrenstein MR, Notley CA. The importance of natural IgM: scavenger, protector and regulator. Nat Rev Immunol. 2010; 10(11):778-86. Epub 2010/10/16. doi:10.1038/nri2849. PubMed PMID: 20948548.

12. Lutz HU, Bussolino F, Flepp R, Fasler S, Stammler P, Kazatchkine MD, et al. Naturally occurring anti-band-3 antibodies and complement together mediate phagocytosis of oxidatively stressed human erythrocytes. Proc Natl Acad Sci USA. 1987;84(21):7368-72. Epub 1987/11/01. PubMed PMID: 3313392; PubMed Central PMCID: PMC299297.

13. Bayry J, Lacroix-Desmazes S, Donkova-Petrini V, Carbonneil C, Misra N, Lepelletier Y, et al. Natural antibodies sustain differentiation and maturation of human dendritic cells. Proc Natl Acad Sci USA. 2004;101(39):14210-5. Epub 2004/09/24. doi:10.1073/pnas.0402183101. PubMed PMID: 15381781; PubMed Central PMCID: PMC521138.

14. Benckert J, Schmolka N, Kreschel C, Zoller MJ, Sturm A, Wiedenmann B, et al. The majority of intestinal IgA+ and IgG+ plasmablasts in the human gut are antigen-specific. The Journal 
of clinical investigation. 2011;121(5):1946-55. Epub 2011/04/ 15. doi:10.1172/JCI44447. PubMed PMID: 21490392; PubMed Central PMCID: PMC3083800.

15. Scheid JF, Mouquet H, Kofer J, Yurasov S, Nussenzweig MC, Wardemann H. Differential regulation of self-reactivity discriminates between $\mathrm{IgG}+$ human circulating memory B cells and bone marrow plasma cells. Proc Natl Acad Sci USA. 2011;108(44):18044-8. Epub 2011/10/26. doi:10.1073/pnas. 1113395108. PubMed PMID: 22025722.

16. Tiller T, Meffre E, Yurasov S, Tsuiji M, Nussenzweig MC, Wardemann H. Efficient generation of monoclonal antibodies from single human B cells by single cell RT-PCR and expression vector cloning. J Immunol Methods. 2008;329(1-2): 112-24. Epub 2007/11/13. doi:10.1016/j.jim.2007.09.017. PubMed PMID: 17996249; PubMed Central PMCID: PMC2243 222.

17. Tiller T, Tsuiji M, Yurasov S, Velinzon K, Nussenzweig MC, Wardemann H. Autoreactivity in human IgG+ memory B cells. Immunity. 2007;26(2):205-13. Epub 2007/02/20. doi:10.1016/ j.immuni.2007.01.009. PubMed PMID: 17306569; PubMed Central PMCID: PMC1839941.

18. Ichiyoshi Y, Casali P. Analysis of the structural correlates for antibody polyreactivity by multiple reassortments of chimeric human immunoglobulin heavy and light chain $\mathrm{V}$ segments. J Exp Med. 1994;180(3):885-95. Epub 1994/09/01. PubMed PMID: 8064239; PubMed Central PMCID: PMC2191637.

19. Liao HX, Chen X, Munshaw S, Zhang R, Marshall DJ, Vandergrift $\mathrm{N}$, et al. Initial antibodies binding to HIV-1 gp41 in acutely infected subjects are polyreactive and highly mutated. J Exp Med. 2011;208(11):2237-49. Epub 2011/10/12. doi: 10.1084/jem.20110363. PubMed PMID: 21987658; PubMed Central PMCID: PMC3201211.

20. Zhou ZH, Zhang Y, Hu YF, Wahl LM, Cisar JO, Notkins AL. The broad antibacterial activity of the natural antibody repertoire is due to polyreactive antibodies. Cell Host Microbe. 2007;1(1):51-61. Epub 2007/11/17. doi:10.1016/j.chom.2007. 01.002. PubMed PMID: 18005681; PubMed Central PMCID: PMC2212603.

21. Ng YS, Wardemann H, Chelnis J, Cunningham-Rundles C, Meffre E. Bruton's tyrosine kinase is essential for human B cell tolerance. J Exp Med. 2004;200(7):927-34. Epub 2004/10/07. doi:10.1084/jem.20040920. PubMed PMID: 15466623; PubMed Central PMCID: PMC2213290.

22. Yurasov S, Wardemann H, Hammersen J, Tsuiji M, Meffre E, Pascual V, et al. Defective B cell tolerance checkpoints in systemic lupus erythematosus. J Exp Med. 2005;201(5):703-11. Epub 2005/03/02. doi:10.1084/jem.20042251. PubMed PMID: 15738055; PubMed Central PMCID: PMC2212839.

23. Wardemann H, Yurasov S, Schaefer A, Young JW, Meffre E, Nussenzweig MC. Predominant autoantibody production by early human B cell precursors. Science. 2003;301(5638): 1374-7. Epub 2003/08/16. doi:10.1126/science.1086907. PubMed PMID: 12920303.

24. Duty JA, Szodoray P, Zheng NY, Koelsch KA, Zhang Q, Swiatkowski M, et al. Functional anergy in a subpopulation of naive B cells from healthy humans that express autoreactive immunoglobulin receptors. J Exp Med. 2009;206(1):139-51. Epub 2008/12/24. doi:10.1084/jem.20080611. PubMed PMID: 19103878; PubMed Central PMCID: PMC2626668.

25. Eschbach C, Bach MP, Fidler I, Pelanda R, Kohler F, Rajewsky K, et al. Efficient generation of B lymphocytes by recognition of selfantigens. Eur J Immunol. 2011;41(8):2397-403. Epub 2011/05/ 24. doi:10.1002/eji.201041344. PubMed PMID: 21604259.

26. Kohler F, Hug E, Eschbach C, Meixlsperger S, Hobeika E, Kofer J, et al. Autoreactive B cell receptors mimic autonomous pre-B cell receptor signaling and induce proliferation of early $B$ cells. Immunity. 2008;29(6):912-21. Epub 2008/12/17. doi: 10.1016/j.immuni.2008.10.013. PubMed PMID: 19084434.

27. Brezinschek HP, Brezinschek RI, Lipsky PE. Analysis of the heavy chain repertoire of human peripheral B cells using singlecell polymerase chain reaction. J Immunol. 1995;155(1):190202. Epub 1995/07/01. PubMed PMID: 7602095.

28. Sui J, Hwang WC, Perez S, Wei G, Aird D, Chen LM, et al. Structural and functional bases for broad-spectrum neutralization of avian and human influenza A viruses. Nature structural \& molecular biology. 2009;16(3):265-73. Epub 2009/02/24. doi: 10.1038/nsmb.1566. PubMed PMID: 19234466; PubMed Central PMCID: PMC2692245.

29. Throsby M, Geuijen C, Goudsmit J, Bakker AQ, Korimbocus J, Kramer RA, et al. Isolation and characterization of human monoclonal antibodies from individuals infected with West Nile Virus. J Virol. 2006;80(14):6982-92. PubMed PMID: 16809304.

30. Ditzel HJ, Itoh K, Burton DR. Determinants of polyreactivity in a large panel of recombinant human antibodies from HIV-1 infection. J Immunol. 1996;157(2):739-49. Epub 1996/07/15. PubMed PMID: 8752924.

31. James LC, Roversi P, Tawfik DS. Antibody multispecificity mediated by conformational diversity. Science. 2003;299(5611): 1362-7. Epub 2003/03/01. doi:10.1126/science.1079731. PubMed PMID: 12610298.

32. Zimmermann J, Romesberg FE, Brooks CL, 3rd, Thorpe IF. Molecular description of flexibility in an antibody combining site. The journal of physical chemistry B. 2010;114(21):735970. Epub 2010/05/12. doi:10.1021/jp906421v. PubMed PMID: 20455589; PubMed Central PMCID: PMC2892760.

33. McMahon MJ, O'Kennedy R. Polyreactivity as an acquired artefact, rather than a physiologic property, of antibodies: evidence that monoreactive antibodies may gain the ability to bind to multiple antigens after exposure to low $\mathrm{pH}$. J Immunol Methods. 2000;241(1-2):1-10. Epub 2000/08/01. PubMed PMID: 10915844.

34. Dimitrov JD, Ivanovska ND, Lacroix-Desmazes S, Doltchinkova VR, Kaveri SV, Vassilev TL. Ferrous ions and reactive oxygen species increase antigen-binding and anti-inflammatory activities of immunoglobulin G. J Biol Chem. 2006;281(1):439-46. Epub 2005/10/26. doi:10.1074/jbc.M509190200. PubMed PMID: 16246843.

35. Mihaylova NM, Dimitrov JD, Djoumerska-Alexieva IK, Vassilev TL. Inflammation-induced enhancement of IgG immunoreactivity. Inflammation research : official journal of the European Histamine Research Society [et al.]. 2008;57(1):1-3. Epub 2008/01/23. doi:10.1007/s00011-007-6213-4. PubMed PMID: 18209958.

36. Matsuda F, Ishii K, Bourvagnet P, Kuma K, Hayashida H, Miyata T, et al. The complete nucleotide sequence of the human immunoglobulin heavy chain variable region locus. J Exp Med. 1998;188(11):2151-62. Epub 1998/12/08. PubMed PMID: 9841928; PubMed Central PMCID: PMC2212390.

37. Berkowska MA, Driessen GJ, Bikos V, Grosserichter-Wagener C, Stamatopoulos K, Cerutti A, et al. Human memory B cells originate from three distinct germinal center-dependent and independent maturation pathways. Blood. 2011;118(8):2150-8. Epub 2011/06/22. doi:10.1182/blood-2011-04-345579. PubMed PMID: 21690558.

38. Wrammert J, Smith K, Miller J, Langley WA, Kokko K, Larsen $\mathrm{C}$, et al. Rapid cloning of high-affinity human monoclonal antibodies against influenza virus. Nature. 2008;453(7195):66771. Epub 2008/05/02. doi:10.1038/nature06890. PubMed PMID: 18449194; PubMed Central PMCID: PMC2515609.

39. Sukupolvi-Petty S, Austin SK, Purtha WE, Oliphant T, Nybakken GE, Schlesinger JJ, et al. Type- and subcomplex-specific neutralizing antibodies against domain III of dengue virus type 2 
envelope protein recognize adjacent epitopes. J Virol. 2007;81(23):12816-26. Epub 2007/09/21. doi:10.1128/ JVI.00432-07. PubMed PMID: 17881453; PubMed Central PMCID: PMC2169112.

40. Brien JD, Austin SK, Sukupolvi-Petty S, O'Brien KM, Johnson $\mathrm{S}$, Fremont DH, et al. Genotype Specific Neutralization and Protection by Antibodies against Dengue Virus Type 3. J Virol. 2010. Epub 2010/08/13. doi:10.1128/JVI.01190-10. PubMed PMID: 20702644.

41. Davenport FM, Hennessy AV, Francis T, Jr. Epidemiologic and immunologic significance of age distribution of antibody to antigenic variants of influenza virus. J Exp Med. 1953;98(6): 641-56. Epub 1953/12/01. PubMed PMID: 13109114; PubMed Central PMCID: PMC2136340.

42. Gulati U, Kumari K, Wu W, Keitel WA, Air GM. Amount and avidity of serum antibodies against native glycoproteins and denatured virus after repeated influenza whole-virus vaccination. Vaccine. 2005;23(11):1414-25. Epub 2005/01/22. doi: 10.1016/j.vaccine.2004.08.053. PubMed PMID: 15661391

43. Kim JH, Skountzou I, Compans R, Jacob J. Original antigenic sin responses to influenza viruses. J Immunol. 2009;183(5): 3294-301. Epub 2009/08/04. doi:10.4049/jimmunol.0900398. PubMed PMID: 19648276.

44. Halstead SB, Rojanasuphot S, Sangkawibha N. Original antigenic sin in dengue. Am J Trop Med Hyg. 1983;32(1):154-6. Epub 1983/01/01. PubMed PMID: 6824120.

45. Midgley CM, Bajwa-Joseph M, Vasanawathana S, Limpitikul W, Wills B, Flanagan A, et al. An in-depth analysis of original antigenic sin in dengue virus infection. J Virol. 2010;85(1):410 21. Epub 2010/10/29. doi:10.1128/JVI.01826-10. PubMed PMID: 20980526; PubMed Central PMCID: PMC3014204.

46. Mongkolsapaya J, Dejnirattisai W, Xu XN, Vasanawathana S, Tangthawornchaikul N, Chairunsri A, et al. Original antigenic sin and apoptosis in the pathogenesis of dengue hemorrhagic fever. Nat Med. 2003;9(7):921-7. PubMed PMID: 12808447.

47. Halstead SB. Dengue. Lancet. 2007;370(9599):1644-52. PubMed PMID: 17993365.

48. Beltramello M, Williams KL, Simmons CP, Macagno A, Simonelli L, Quyen NT, et al. The human immune response to Dengue virus is dominated by highly cross-reactive antibodies endowed with neutralizing and enhancing activity. Cell Host Microbe. 2010;8(3):271-83. Epub 2010/09/14. doi:10.1016/ j.chom.2010.08.007. PubMed PMID: 20833378.

49. Crill WD, Hughes HR, Delorey MJ, Chang GJ. Humoral immune responses of dengue fever patients using epitope-specific serotype-2 virus-like particle antigens. PLoS One. 2009;4(4):e4991. Epub 2009/04/02. doi:10.1371/journal.pone. 0004991. PubMed PMID: 19337372; PubMed Central PMCID: PMC2659788.

50. Dejnirattisai W, Jumnainsong A, Onsirisakul N, Fitton P, Vasanawathana S, Limpitikul W, et al. Cross-reacting antibodies enhance dengue virus infection in humans. Science. 2010; 328(5979):745-8. Epub 2010/05/08. doi:10.1126/science. 1185181. PubMed PMID: 20448183.

51. Lai CY, Tsai WY, Lin SR, Kao CL, Hu HP, King CC, et al. Antibodies to envelope glycoprotein of dengue virus during the natural course of infection are predominantly cross-reactive and recognize epitopes containing highly conserved residues at the fusion loop of domain II. J Virol. 2008;82(13):6631-43. PubMed PMID: 18448542.

52. Schieffelin JS, Costin JM, Nicholson CO, Orgeron NM, Fontaine KA, Isern $\mathrm{S}$, et al. Neutralizing and non-neutralizing monoclonal antibodies against dengue virus $\mathrm{E}$ protein derived from a naturally infected patient. Virol J. 2010;7:28. Epub 2010/02/06. doi:10.1186/1743-422X-7-28. PubMed PMID: 20132551; PubMed Central PMCID: PMC2829534.
53. de Alwis R, Beltramello M, Messer WB, Sukupolvi-Petty S, Wahala WM, Kraus A, et al. In-depth analysis of the antibody response of individuals exposed to primary dengue virus infection. PLoS Negl Trop Dis. 2011;5(6):e1188. Epub 2011/06/30. doi:10.1371/journal.pntd.0001188. PubMed PMID: 21713020; PubMed Central PMCID: PMC3119640.

54. Mathew A, West K, Kalayanarooj S, Gibbons RV, Srikiatkhachorn A, Green S, et al. B-cell responses during primary and secondary dengue virus infections in humans. J Infect Dis. 2011;204(10):1514-22. Epub 2011/09/21. doi:10.1093/infdis/ jir607. PubMed PMID: 21930609.

55. Mikell I, Sather DN, Kalams SA, Altfeld M, Alter G, Stamatatos L. Characteristics of the earliest cross-neutralizing antibody response to HIV-1. PLoS Pathog. 2011;7(1):e1001251. Epub 2011/01/21. doi:10.1371/journal.ppat.1001251. PubMed PMID: 21249232; PubMed Central PMCID: PMC3020924.

56. Stamatatos L, Morris L, Burton DR, Mascola JR. Neutralizing antibodies generated during natural HIV-1 infection: good news for an HIV-1 vaccine? Nature medicine. 2009;15(8):866-70. Epub 2009/06/16. doi:10.1038/nm.1949. PubMed PMID: 19525964.

57. Deeks SG, Schweighardt B, Wrin T, Galovich J, Hoh R, Sinclair E, et al. Neutralizing antibody responses against autologous and heterologous viruses in acute versus chronic human immunodeficiency virus (HIV) infection: evidence for a constraint on the ability of HIV to completely evade neutralizing antibody responses. J Virol. 2006;80(12):6155-64. Epub 2006/05/30. doi: 10.1128/JVI.00093-06. PubMed PMID: 16731954; PubMed Central PMCID: PMC1472617.

58. Sather DN, Armann J, Ching LK, Mavrantoni A, Sellhorn G, Caldwell Z, et al. Factors associated with the development of cross-reactive neutralizing antibodies during human immunodeficiency virus type 1 infection. J Virol. 2009;83(2):757-69. Epub 2008/11/07. doi:10.1128/JVI.02036-08. PubMed PMID: 18987148; PubMed Central PMCID: PMC2612355.

59. Euler Z, van Gils MJ, Bunnik EM, Phung P, Schweighardt B, Wrin $\mathrm{T}$, et al. Cross-reactive neutralizing humoral immunity does not protect from HIV type 1 disease progression. J Infect Dis. 2010;201(7):1045-53. Epub 2010/02/23. doi:10.1086/651 144. PubMed PMID: 20170371.

60. Piantadosi A, Panteleeff D, Blish CA, Baeten JM, Jaoko W, McClelland RS, et al. Breadth of neutralizing antibody response to human immunodeficiency virus type 1 is affected by factors early in infection but does not influence disease progression. J Virol. 2009;83(19):10269-74. Epub 2009/07/31. doi:10.1128/ JVI.01149-09. PubMed PMID: 19640996; PubMed Central PMCID: PMC2748011.

61. Doria-Rose NA, Klein RM, Daniels MG, O’Dell S, Nason M, Lapedes A, et al. Breadth of human immunodeficiency virusspecific neutralizing activity in sera: clustering analysis and association with clinical variables. J Virol. 2010;84(3):1631-6. Epub 2009/11/20. doi:10.1128/JVI.01482-09. PubMed PMID: 19923174; PubMed Central PMCID: PMC2812355.

62. Mondelli MU, Cerino A, Lisa A, Brambilla S, Segagni L, Cividini A, et al. Antibody responses to hepatitis $\mathrm{C}$ virus hypervariable region 1: evidence for cross-reactivity and immune-mediated sequence variation. Hepatology. 1999;30(2): 537-45. Epub 1999/07/27. doi:10.1002/hep.510300233. PubMed PMID: 10421665.

63. Osburn WO, Fisher BE, Dowd KA, Urban G, Liu L, Ray SC, et al. Spontaneous control of primary hepatitis $\mathrm{C}$ virus infection and immunity against persistent reinfection. Gastroenterology. 2010;138(1):315-24. Epub 2009/09/29. doi:10.1053/j.gastro. 2009.09.017. PubMed PMID: 19782080; PubMed Central PMCID: PMC2889495.

64. Halstead. Immunopathological parameters of togavirus disease syndromes. W S, editor. New York: Academic Press; 1980. 
65. Kurane I EF. Immunopathogenesis of dengue virus infections. Gubler DJ KG, editor. Oxon, UK: CBA International; 1997.

66. Vaughn DW, Green S, Kalayanarooj S, Innis BL, Nimmannitya S, Suntayakorn S, et al. Dengue viremia titer, antibody response pattern, and virus serotype correlate with disease severity. J Infect Dis. 2000;181(1):2-9. Epub 1999/12/23. doi:10.1086/ 315215. PubMed PMID: 10608744.

67. Goncalvez AP, Engle RE, St Claire M, Purcell RH, Lai CJ. Monoclonal antibody-mediated enhancement of dengue virus infection in vitro and in vivo and strategies for prevention. Proc Natl Acad Sci USA. 2007;104(22):9422-7. Epub 2007/05/23. doi:10.1073/pnas.0703498104. PubMed PMID: 17517625; PubMed Central PMCID: PMC1868655.

68. Guzman MG, Alvarez M, Rodriguez-Roche R, Bernardo L, Montes $T$, Vazquez $S$, et al. Neutralizing antibodies after infection with dengue 1 virus. Emerg Infect Dis. 2007;13(2): 282-6. Epub 2007/05/08. PubMed PMID: 17479892; PubMed Central PMCID: PMC2725871.

69. Halstead SB, Scanlon JE, Umpaivit P, Udomsakdi S. Dengue and chikungunya virus infection in man in Thailand, 1962-1964. IV. Epidemiologic studies in the Bangkok metropolitan area. Am J Trop Med Hyg. 1969;18(6):997-1021. Epub 1969/11/01. PubMed PMID: 4390977.

70. Libraty DH, Acosta LP, Tallo V, Segubre-Mercado E, Bautista A, Potts JA, et al. A prospective nested case-control study of Dengue in infants: rethinking and refining the antibody-dependent enhancement dengue hemorrhagic fever model. PLoS Med. 2009;6(10):e1000171. Epub 2009/10/28. doi:10.1371/journal. pmed.1000171. PubMed PMID: 19859541; PubMed Central PMCID: PMC2762316.

71. Schmidt AC. Response to dengue fever-the good, the bad, and the ugly? N Engl J Med. 2010;363(5):484-7. Epub 2010/09/08. doi:10.1056/NEJMcibr1005904. PubMed PMID: 20818870.

72. Guzman MG, Kouri GP, Bravo J, Soler M, Vazquez S, Morier L. Dengue hemorrhagic fever in Cuba, 1981: a retrospective seroepidemiologic study. Am J Trop Med Hyg. 1990;42(2):179-84. Epub 1990/02/01. PubMed PMID: 2316788.

73. Sullivan NJ. Antibody-mediated enhancement of viral disease. Curr Top Microbiol Immunol. 2001;260:145-69. Epub 2001/07/ 11. PubMed PMID: 11443872.

74. Rulli NE, Suhrbier A, Hueston L, Heise MT, Tupanceska D, Zaid A, et al. Ross River virus: molecular and cellular aspects of disease pathogenesis. Pharmacol Ther. 2005;107(3):329-42. Epub 2005/06/01. doi:10.1016/j.pharmthera.2005.03.006. PubMed PMID: 15923040.

75. Klimstra WB, Williams JC, Ryman KD, Heidner HW. Targeting Sindbis virus-based vectors to $\mathrm{Fc}$ receptor-positive cell types. Virology. 2005;338(1):9-21. Epub 2005/06/01. doi:10.1016/ j.virol.2005.04.039. PubMed PMID: 15922395.

76. Rodenhuis-Zybert IA, van der Schaar HM, da Silva Voorham JM, van der Ende-Metselaar H, Lei HY, Wilschut J, et al. Immature dengue virus: a veiled pathogen? PLoS Pathog. 2010;6(1):e1000718. Epub 2010/01/12. doi:10.1371/journal. ppat.1000718. PubMed PMID: 20062797; PubMed Central PMCID: PMC2798752.

77. Pierson TC, Xu Q, Nelson S, Oliphant T, Nybakken GE, Fremont $\mathrm{DH}$, et al. The stoichiometry of antibody-mediated neutralization and enhancement of West Nile virus infection. Cell Host Microbe. 2007;1(2):135-45. Epub 2007/11/17. doi: 10.1016/j.chom.2007.03.002. PubMed PMID: 18005691; PubMed Central PMCID: PMC2656919.

78. Krilov LR, Anderson LJ, Marcoux L, Bonagura VR, Wedgwood JF. Antibody-mediated enhancement of respiratory syncytial virus infection in two monocyte/macrophage cell lines. J Infect Dis. 1989;160(5):777-82. Epub 1989/11/01. PubMed PMID: 2809253.
79. Yao JS, Kariwa H, Takashima I, Yoshimatsu K, Arikawa J, Hashimoto N. Antibody-dependent enhancement of hantavirus infection in macrophage cell lines. Arch Virol. 1992;122(1-2): 107-18. Epub 1992/01/01. PubMed PMID: 1370367.

80. Takada A, Feldmann H, Ksiazek TG, Kawaoka Y. Antibodydependent enhancement of Ebola virus infection. J Virol. 2003;77(13):7539-44. Epub 2003/06/14. PubMed PMID: 12805454; PubMed Central PMCID: PMC164833.

81. Meyer K, Ait-Goughoulte M, Keck ZY, Foung S, Ray R. Antibody-dependent enhancement of hepatitis $\mathrm{C}$ virus infection. J Virol. 2008;82(5):2140-9. Epub 2007/12/21. doi:10.1128/JVI. 01867-07. PubMed PMID: 18094180; PubMed Central PMCID: PMC2258956.

82. Willey S, Aasa-Chapman MM, O'Farrell S, Pellegrino P, Williams I, Weiss RA, et al. Extensive complement-dependent enhancement of HIV-1 by autologous non-neutralising antibodies at early stages of infection. Retrovirology. 2011;8:16. Epub 2011/03/16. doi:10.1186/1742-4690-8-16. PubMed PMID: 21401915; PubMed Central PMCID: PMC3065417.

83. Gimenez HB, Chisholm S, Dornan J, Cash P. Neutralizing and enhancing activities of human respiratory syncytial virus-specific antibodies. Clin Diagn Lab Immunol. 1996;3(3):280-6. Epub 1996/05/01. PubMed PMID: 8705669; PubMed Central PMCID: PMC170331.

84. Lagging LM, Meyer K, Westin J, Wejstal R, Norkrans G, Lindh $\mathrm{M}$, et al. Neutralization of pseudotyped vesicular stomatitis virus expressing hepatitis $\mathrm{C}$ virus envelope glycoprotein 1 or 2 by serum from patients. J Infect Dis. 2002;185(8): 1165-9. Epub 2002/04/04. doi:10.1086/339679. PubMed PMID: 11930327.

85. Rothman AL, Morishima C, Bonkovsky HL, Polyak SJ, Ray R, Di Bisceglie AM, et al. Associations among clinical, immunological, and viral quasispecies measurements in advanced chronic hepatitis C. Hepatology. 2005;41(3):617-25. Epub 2005/02/24. doi:10.1002/hep.20581. PubMed PMID: 15726656.

86. Morishima C, Polyak SJ, Ray R, Doherty MC, Di Bisceglie AM, Malet $P F$, et al. Hepatitis $C$ virus-specific immune responses and quasi-species variability at baseline are associated with nonresponse to antiviral therapy during advanced hepatitis C. J Infect Dis. 2006;193(7):931-40. Epub 2006/03/07. doi:10.1086/ 500952. PubMed PMID: 16518754.

87. Ray R, Meyer K, Banerjee A, Basu A, Coates S, Abrignani S, et al. Characterization of antibodies induced by vaccination with hepatitis C virus envelope glycoproteins. J Infect Dis. 2010; 202(6):862-6. Epub 2010/08/04. doi:10.1086/655902. PubMed PMID: 20677942; PubMed Central PMCID: PMC2931414.

88. Yu Q, Yu R, Qin X. The good and evil of complement activation in HIV-1 infection. Cell Mol Immunol. 2010;7(5):334-40. Epub 2010/03/17. doi:10.1038/cmi.2010.8. PubMed PMID: 20228 834.

89. Gras GS, Dormont D. Antibody-dependent and antibody-independent complement-mediated enhancement of human immunodeficiency virus type 1 infection in a human, Epstein-Barr virus-transformed B-lymphocytic cell line. J Virol. 1991;65(1): 541-5. Epub 1991/01/01. PubMed PMID: 1845908; PubMed Central PMCID: PMC240554.

90. Srikiatkhachorn A. Plasma leakage in dengue haemorrhagic fever. Thromb Haemost. 2009;102(6):1042-9. Epub 2009/12/08. doi:10.1160/TH09-03-0208. PubMed PMID: 19967133.

91. Rothman AL. Immunity to dengue virus: a tale of original antigenic sin and tropical cytokine storms. Nat Rev Immunol. 2011;11(8):532-43. Epub 2011/07/16. doi:10.1038/nri3014. PubMed PMID: 21760609.

92. Lin CF, Lei HY, Liu CC, Liu HS, Yeh TM, Wang ST, et al. Generation of IgM anti-platelet autoantibody in dengue patients. J Med Virol. 2001;63(2):143-9. Epub 2001/02/15. doi: 
10.1002/1096-9071(20000201)63:2<143::AID-JMV1009>3.0. CO;2-L. PubMed PMID: 11170051.

93. Lin CF, Lei HY, Shiau AL, Liu CC, Liu HS, Yeh TM, et al. Antibodies from dengue patient sera cross-react with endothelial cells and induce damage. J Med Virol. 2003;69(1):82-90. Epub 2002/11/19. doi:10.1002/jmv.10261. PubMed PMID: 12436482.

94. Lin C. Autoimmunity in dengue virus infection. Dengue Bull. 2004;28:51-7.

95. Liu IJ, Chiu CY, Chen YC, Wu HC. Molecular mimicry of human endothelial cell antigen by autoantibodies to nonstructural protein 1 of dengue virus. J Biol Chem. 2011;286(11): 9726-36. Epub 2011/01/15. doi:10.1074/jbc.M110.170993. PubMed PMID: 21233208; PubMed Central PMCID: PMC30 58979.

96. Misra A, Mukerjee R, Chaturvedi UC. Production of nitrite by dengue virus-induced cytotoxic factor. Clin Exp Immunol. 1996;104(3):406-11. Epub 1996/06/01. PubMed PMID: 90999 23; PubMed Central PMCID: PMC2200459.

97. Lin YS, Yeh TM, Lin CF, Wan SW, Chuang YC, Hsu TK, et al. Molecular mimicry between virus and host and its implications for dengue disease pathogenesis. Exp Biol Med (Maywood). 2011;236(5):515-23. Epub 2011/04/20. doi:10.1258/ebm.2011. 010339. PubMed PMID: 21502191.

98. Markoff LJ, Innis BL, Houghten R, Henchal LS. Development of cross-reactive antibodies to plasminogen during the immune response to dengue virus infection. J Infect Dis. 1991;164(2): 294-301. Epub 1991/08/01. PubMed PMID: 1856477.

99. Chungue E, Poli L, Roche C, Gestas P, Glaziou P, Markoff LJ. Correlation between detection of plasminogen cross-reactive antibodies and hemorrhage in dengue virus infection. J Infect Dis. 1994;170(5):1304-7. Epub 1994/11/01. PubMed PMID: 7963733.

100. Huang YH, Chang BI, Lei HY, Liu HS, Liu CC, Wu HL, et al. Antibodies against dengue virus $\mathrm{E}$ protein peptide bind to human plasminogen and inhibit plasmin activity. Clin Exp Immunol. 1997;110(1):35-40. Epub 1997/11/14. PubMed PMID: 9353146; PubMed Central PMCID: PMC1904795.

101. Bettaieb. Cross-reactive antibodies between HIV-gp120 and platelet gpIIIa (CD61) in HIV-related immune thrombocytopenic purpura. Clin Exp Immunol. 1996;103(1):19-23.

102. Zhang W, Nardi MA, Borkowsky W, Li Z, Karpatkin S. Role of molecular mimicry of hepatitis $\mathrm{C}$ virus protein with platelet GPIIIa in hepatitis C-related immunologic thrombocytopenia. Blood. 2009;113(17):4086-93. Epub 2008/11/22. doi: 10.1182/blood-2008-09-181073. PubMed PMID: 19023115; PubMed Central PMCID: PMC2673130.

103. Marceau G, Lapierre P, Beland K, Soudeyns H, Alvarez F. LKM1 autoantibodies in chronic hepatitis $C$ infection: a case of molecular mimicry? Hepatology. 2005;42(3):675-82. Epub 2005/07/23. doi:10.1002/hep.20816. PubMed PMID: 16037945.

104. Sansonno D, Tucci FA, Ghebrehiwet B, Lauletta G, Peerschke EI, Conteduca V, et al. Role of the receptor for the globular domain of $\mathrm{C} 1 \mathrm{q}$ protein in the pathogenesis of hepatitis $\mathrm{C}$ virusrelated cryoglobulin vascular damage. J Immunol. 2009;183(9):6013-20. Epub 2009/10/16. doi:10.4049/jimmunol. 0902038. PubMed PMID: 19828637; PubMed Central PMCID: PMC2794553.

105. Crowson AN, Magro CM. Recent advances in the pathology of cutaneous drug eruptions. Dermatologic clinics. 1999;17(3): 537-60, viii. Epub 1999/07/20. PubMed PMID: 10410857.

106. Nocente R, Ceccanti M, Bertazzoni G, Cammarota G, Silveri NG, Gasbarrini G. HCV infection and extrahepatic manifestations. Hepato-gastroenterology. 2003;50(52):1149-54. Epub 2003/07/09. PubMed PMID: 12846002.

107. Simmonds P, Bukh J, Combet C, Deleage G, Enomoto N, Feinstone $\mathrm{S}$, et al. Consensus proposals for a unified system of nomenclature of hepatitis $\mathrm{C}$ virus genotypes. Hepatology. 2005;42(4):962-73. Epub 2005/09/09. doi:10.1002/hep.20819. PubMed PMID: 16149085.

108. Hay AJ, Gregory V, Douglas AR, Lin YP. The evolution of human influenza viruses. Philosophical transactions of the Royal Society of London Series B, Biological sciences. 2001; 356(1416):1861-70. Epub 2002/01/10. doi:10.1098/rstb.2001. 0999. PubMed PMID: 11779385; PubMed Central PMCID: PMC1088562.

109. Wu X, Zhou T, Zhu J, Zhang B, Georgiev I, Wang C, et al. Focused evolution of HIV-1 neutralizing antibodies revealed by structures and deep sequencing. Science. 2011;333(6049):1593602. Epub 2011/08/13. doi:10.1126/science.1207532. PubMed PMID: 21835983.

110. Ekiert DC, Friesen RH, Bhabha G, Kwaks T, Jongeneelen M, $\mathrm{Yu} \mathrm{W}$, et al. A highly conserved neutralizing epitope on group 2 influenza A viruses. Science. 2011;333(6044):843-50. Epub 2011/07/09. doi:10.1126/science.1204839. PubMed PMID: 21737702; PubMed Central PMCID: PMC3210727.

111. Ichiyoshi Y, Zhou M, Casali P. A human anti-insulin IgG autoantibody apparently arises through clonal selection from an insulin-specific "germ-line" natural antibody template. Analysis by $\mathrm{V}$ gene segment reassortment and site-directed mutagenesis. J Immunol. 1995;154(1):226-38. Epub 1995/01/01. PubMed PMID: 7995943.

112. Martin T, Crouzier R, Weber JC, Kipps TJ, Pasquali JL. Structure-function studies on a polyreactive (natural) autoantibody. Polyreactivity is dependent on somatically generated sequences in the third complementarity-determining region of the antibody heavy chain. J Immunol. 1994;152(12):5988-96. Epub 1994/06/15. PubMed PMID: 8207223.

113. Haynes BF, Fleming J, St Clair EW, Katinger H, Stiegler G, Kunert R, et al. Cardiolipin polyspecific autoreactivity in two broadly neutralizing HIV-1 antibodies. Science. 2005; 308(5730):1906-8. Epub 2005/04/30. doi:10.1126/science.111 1781. PubMed PMID: 15860590.

114. Morris L, Chen X, Alam M, Tomaras G, Zhang R, Marshall DJ, et al. Isolation of a human anti-HIV gp41 membrane proximal region neutralizing antibody by antigen-specific single $\mathrm{B}$ cell sorting. PLoS One. 2011;6(9):e23532. Epub 2011/10/08. doi: 10.1371/journal.pone.0023532. PubMed PMID: 21980336; PubMed Central PMCID: PMC3184076.

115. Mouquet H, Klein F, Scheid JF, Warncke M, Pietzsch J, Oliveira TY, et al. Memory B cell antibodies to HIV-1 gp140 cloned from individuals infected with clade A and B viruses. PLoS One. 2011;6(9):e24078. Epub 2011/09/21. doi:10.1371/journal.pone. 0024078. PubMed PMID: 21931643; PubMed Central PMCID: PMC3169578.

116. Scheid JF, Mouquet H, Feldhahn N, Seaman MS, Velinzon K, Pietzsch J, et al. Broad diversity of neutralizing antibodies isolated from memory B cells in HIV-infected individuals. Nature. 2009;458(7238):636-40. Epub 2009/03/17. doi:10.1038/ nature07930. PubMed PMID: 19287373.

117. Harindranath N, Ikematsu H, Notkins AL, Casali P. Structure of the $\mathrm{VH}$ and $\mathrm{VL}$ segments of polyreactive and monoreactive human natural antibodies to HIV-1 and Escherichia coli betagalactosidase. International immunology. 1993;5(12):1523-33. Epub 1993/12/01. PubMed PMID: 8312222.

118. Warsame AA, Aasheim HC, Nustad K, Troen G, Tierens A, Wang V, et al. Splenic marginal zone lymphoma with VH1-02 gene rearrangement expresses poly- and self-reactive antibodies with similar reactivity. Blood. 2011;118(12):3331-9. Epub 2011/07/05. doi:10.1182/blood-2011-03-341651. PubMed PMID: 21725051.

119. Ekiert DC, Bhabha G, Elsliger MA, Friesen RH, Jongeneelen M, Throsby M, et al. Antibody recognition of a highly conserved 
influenza virus epitope. Science. 2009;324(5924):246-51. Epub 2009/03/03. doi:10.1126/science.1171491. PubMed PMID: 19251591; PubMed Central PMCID: PMC2758658.

120. Throsby M, van den Brink E, Jongeneelen M, Poon LL, Alard P, Cornelissen L, et al. Heterosubtypic neutralizing monoclonal antibodies cross-protective against $\mathrm{H} 5 \mathrm{~N} 1$ and $\mathrm{H} 1 \mathrm{~N} 1$ recovered from human IgM+ memory B cells. PloS one. 2008;3(12): e3942. Epub 2008/12/17. doi:10.1371/journal.pone.0003942. PubMed PMID: 19079604; PubMed Central PMCID: PMC25 96486.

121. Chan CH, Hadlock KG, Foung SK, Levy S. V(H)1-69 gene is preferentially used by hepatitis $\mathrm{C}$ virus-associated $\mathrm{B}$ cell lymphomas and by normal $\mathrm{B}$ cells responding to the $\mathrm{E} 2$ viral antigen. Blood. 2001;97(4):1023-6. Epub 2001/02/13. PubMed PMID: 11159532.

122. Ivanovski M, Silvestri F, Pozzato G, Anand S, Mazzaro C, Burrone OR, et al. Somatic hypermutation, clonal diversity, and preferential expression of the $\mathrm{VH}$ 51p1/VL kv325 immunoglobulin gene combination in hepatitis $\mathrm{C}$ virus-associated immunocytomas. Blood. 1998;91(7):2433-42. Epub 1998/04/18. PubMed PMID: 9516143.

123. Craig VJ, Arnold I, Gerke C, Huynh MQ, Wundisch T, Neubauer A, et al. Gastric MALT lymphoma B cells express polyreactive, somatically mutated immunoglobulins. Blood. 2010;115(3):581-91. Epub 2009/12/08. doi:10.1182/blood2009-06-228015. PubMed PMID: 19965661.

124. Vaughn DW, Green S, Kalayanarooj S, Innis BL, Nimmannitya S, Suntayakorn S, et al. Dengue in the early febrile phase: viremia and antibody responses. J Infect Dis. 1997; 176(2):322-30. PubMed PMID: 9237696.

125. Wrammert J, Koutsonanos D, Li GM, Edupuganti S, Sui J, Morrissey M, et al. Broadly cross-reactive antibodies dominate the human B cell response against 2009 pandemic H1N1 influenza virus infection. J Exp Med. 2011;208(1):181-93. Epub 2011/01/12. doi:10.1084/jem.20101352. PubMed PMID: 21220454; PubMed Central PMCID: PMC3023136.

126. Galli G, Hancock K, Hoschler K, DeVos J, Praus M, Bardelli M, et al. Fast rise of broadly cross-reactive antibodies after boosting long-lived human memory B cells primed by an MF59 adjuvanted prepandemic vaccine. Proc Natl Acad Sci USA. 2009;106(19):7962-7. Epub 2009/05/07. doi:10.1073/pnas.0903 181106. PubMed PMID: 19416838; PubMed Central PMCID: PMC2674105. 